\title{
Margaret McCartney: Evidence in a post-truth world
}

\author{
Margaret McCartney general practitioner
}

Glasgow

Is the internet making us more stupid? The outcome of the US presidential election will be analysed as a caustic case study long after we're all dead, but the internet must take at least some of the blame. We're in a post-fact, post-truth, we've-had-enough-of-experts era.

I remember realising that knowledge no longer meant a date with Index Medicus (young people: this was a multi-volume, paper-paper!-bibliography that started the hours-long search for research, during library opening hours only). The internet has driven through multiple barriers and has made resources such as Testing Treatments, Understanding Uncertainty, or open online courses available to anyone with an internet connection who wants to learn about evidence.

For every one of these, however, there are multiple seams of misinformation spilling between press offices, public relations companies, and newspapers, exacerbated by a love of catchy headlines and a disregard for expressing uncertainty. Yet, when there is little uncertainty-for example, in climate change science or the non-link between vaccination and autism-each "side" is often afforded the same gravitas, so the public sees a debate instead of a clear consensus.

Conspiracy theories aren't new. But the unbridled internet brims with "fake news," now out of control. Anyone can publish unchecked stories, which can be disseminated instantly to millions. False claims that Pope Francis supported Donald Trump, or that an FBI officer investigating Hillary Clinton's emails was murdered, took root.

One analysis has found that the top 20 fake news stories outperformed "real" news stories in the weeks before the US election. ${ }^{1}$ Such internet platforms survive and thrive through advertising, with clickbait as the currency. The more lurid the headline, the more dollars in the pocket.

Each "side" is often afforded the same gravitas, so the public sees a debate instead of a clear consensus
Facebook and Google have now said, too late, that they will try to remove advertising by propagators of fake news. ${ }^{2}$ As Barack Obama put it, "If we are not serious about facts and what's true and what's not, if we can't discriminate between serious arguments and propaganda, then we have problems." 3

Those problems are urgent and potentially disastrous: vaccinations, climate change, poverty, sexuality, and contraception rights. A country seen as progressive, but going backwards, harms us all.

What can we do? I'd suggest two things. Firstly, know who your elected representatives are, and make sure that they know the value of evidence in decision making. Keep an eye on the decisions they take on your behalf. Secondly, subscribe to at least one newspaper that funds investigative journalism and fact checking. Write to it at least twice a year-once to praise, once to offer constructive criticism when it covers a subject you know about.

Expertise should not be elitist. It should be a resource for everyone.

Competing interests: See www.bmj.com/about-bmj/freelancecontributors/margaret-mccartney.

Provenance and peer review: Commissioned; not externally peer reviewed.

Follow Margaret on Twitter, @mgtmccartney

Silverman C. This analysis shows how fake election news stories outperformed real news on Facebook. BuzzFeed 2016 Nov 16. https://www buzzfeed.com/craigsilverman/viralfake-election-news-outperformed-real-news-on-facebook?utm_term=.aoRZp41VdK\#. rqkodZkMJG.

2 Hern A. Facebook and Google move to kick fake news sites off their ad networks. Guardian 2016 Nov 15. https://www.theguardian.com/technology/2016/nov/15/facebook-googlefake-news-sites-ad-networks.

3 Solon O. Barack Obama on fake news: "We have problems" if we can't tell the difference. Guardian 2016 Nov 18. https://www.theguardian.com/media/2016/nov/17/barack-obamafake-news-facebook-social-media.

Published by the BMJ Publishing Group Limited. For permission to use (where not already granted under a licence) please go to http://group.bmj.com/group/rights-licensing/ permissions 